
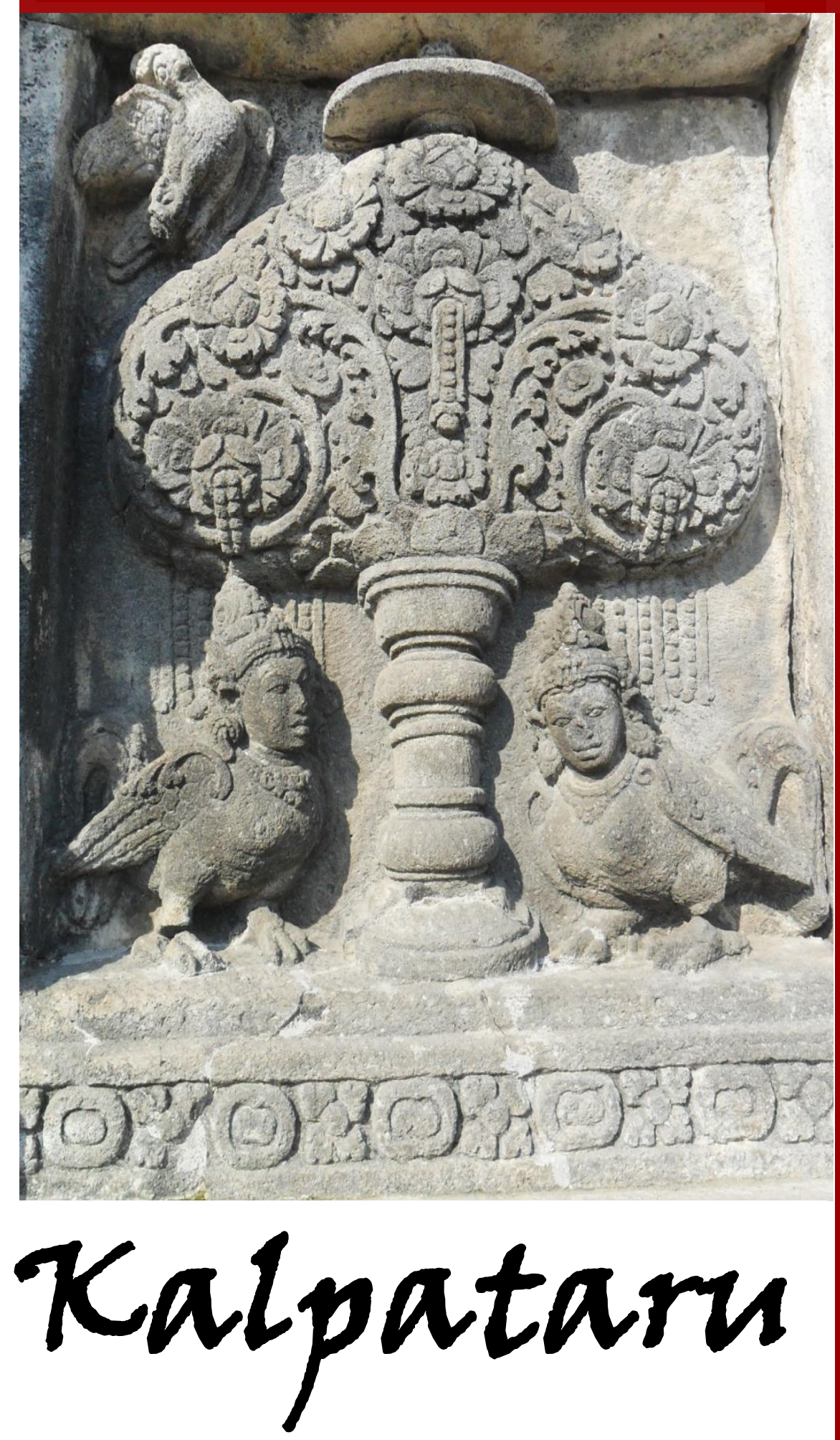

JURNAL SEJARAH DAN PEMBELAJARAN SEJARAH

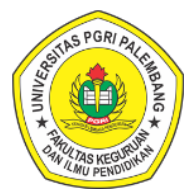

Program Studi Pendidikan Sejarah Jurusan Pendidikan IPS

Fakultas Keguruan dan IImu Pendidikan Universitas Persatuan Guru Republik Indonesia Palembang
Pengaruh Penerapan Model Project Based Learning Berbasis Video Vlog Dalam Proses Pembelajaran Sejarah Farena Adela, Nur Ahyani, Dina Sri Nindiati

Identifikasi Nilai Pedagogi Pada Pahatan Monolid Desa Jarakan Sebagai Sumber Pembelaran Sejarah Alzata Putra, Sukardi, Aan Suriadi

Nilai Sejarah Makam Puyang Ulak Laut di Pecah Pinggan Sebagai Sumber Pembelajaran Sejarah Berbasis Digital Dewi Cahya, Sukardi, Eva Dina Chairunisa

Pola Sebaran Permukiman di Kota Kayu Agung

I Made Lingga Wardana, Sukardi, Wandiyo

Peran Adam Malik Sebagai Ketua Sidang Majelis Umum PBB 1971 Rani Noviyanti

Pemanfaatan Foto dan Arsip Sebagai Sumber Pembelajaran Sejarah Riki Andi Saputro, Muhammad Fitri

Nilai-Nilai Sejarah Puyang Muara Rambang Sebagai Sumber Pelajaran Sejarah Lokal di SMA 01 Muarakuang Dwi Cahyati, Sukardi, Eva Dina Chairunisa

Pemikiran Abdul Mukti Ali Sebagai Sumber Pembelajaran Sejarah di SMA Patra Mandiri 1 Palembang Andika Merryanto Saputra, Aan Suriadi, Ahmad Zamhari

Perjuangan Hj. Rangkayo Rasuna Said Sebagai Pejuang Politik dan Pemikir Pergerakan Pada Masa Pra Kemerdekaan

Narani Agesti, Ageng Sanjaya

Nilai Sosial Religi Tradisi Manopeng Pada Masyarakat Banyiur Muhammad Fitri, Heri Susanto 
Kalpataru, Volume 7, Nomor 2, Desember 2021 (83-89)

\title{
PENGARUH PENERAPAN MODEL PROJECT BASED LEARNING BERBASIS VIDEO VLOG DALAM PROSES PEMBELAJARAN SEJARAH
}

\author{
Farena Adela \\ Mahasiswa Program Studi Pendidikan Sejarah, FKIP Univeraitas PGRI Palembang \\ Email: farenaadela0@gmail.com \\ Nur Ahyani \\ Dosen Program Studi Pendidikan Sejarah, FKIP Universitas PGRI Palembang \\ Email: nurahyani_sj@univpgri-palembang.ac.id \\ Dina Sri Nindiati \\ Dosen Program Studi Pendidikan Sejarah, FKIP Universitas PGRI Palembang \\ Email: dinamrsyid@gmail.com
}

\begin{abstract}
ABSTRAK
Model pembelajaran merupakan suatu struktur pembelajaran yang telah disusun, didesain, dan ditetapkan untuk mencapai suatu tujuan pembelajaran yang diinginkan. Adapun masalah di dalam penelitian ini ialah adakah pengaruh penerapan model project based learning berbasis video vlog dalam proses pembelajaran sejarah. Tujuan penelitian ini adalah untuk mengetahui ada tidaknya pengaruh penerapan model project based learning berbasis video vlog dalam proses pembelajaran sejarah. Populasi dalam penelitian ini adalah siswa kelas X di UPT SMA Negeri 7 Banyuasin dan sampel dalam penelitian ini adalah siswa kelas X IPS 2 dengan jumlah siswa 15 orang sebagai kelas eksperimen dan kelas X IPS 1 dengan jumlah siswa 15 orang sebagai kelas kontrol. Dari hasil penelitian terbukti bahwa "ada pengaruh penerapan model project based learning berbasis video vlog dalam proses pembelajaran sejarah". Dengan nilai rata-rata kelas eksperimen 83 sedangkan kelas kontrol 55, sehingga di dapat thitung $=12.02$ dant $_{\text {tabel }}=1,701$. Dengan ini dapat disimpulkan thitung $>t_{\text {tabel }}$ sehingga $\mathrm{H}_{0}$ ditolak dan $\mathrm{H}_{\mathrm{a}}$ diterima.
\end{abstract}

Kata Kunci: Model Pembelajaran, Project Based Learning, Proses Pembelajaran Sejarah.

\section{A. PENDAHULUAN}

Pengajaran merupakan upaya yang terkoordinasi, teratur dan konsisten (tahan lama) untuk membina mahasiswa menjadi individu yang total, berkembang dan beradab (Ahyani, 2014:94).

Pembelajaran yang menarik adalah ukuran pembelajaran yang tidak hanya berpusat pada hasil yang dicapai oleh siswa, namun bagaimana ukuran pembelajaran yang kuat dapat memberikan kesepakatan, pengetahuan, ketekunan, kesempatan, dan kualitas yang layak dan dapat memberikan perubahan perilaku dan menerapkannya untuk hidup mereka. Pembelajaran yang berhasil dapat menanamkan karakter aturan mayoritas untuk siswa yang akan membuat siklus pembelajaran benar-benar menyenangkan dan dapat mendorong imajinasi siswa dalam mengkomunikasikan penilaian mereka. Untuk mengakui pembelajaran yang memaksa, diperlukan suatu teknik dalam ukuran pembelajaran kreatif (Fakhrurrazi, 2018:87).

Model pembelajaran yang menjadikan siswa leluasa dalam belajar dan dapat berbaur serta memiliki jiwa administrasi salah satunya yaitu model pembelajaran inovasi. Pembelajaran inovasi diciptakan untuk mencapai hasil belajar sebagai pencapaian skolastik, perlawanan, pengakuan variasi dan peningkatan kemampuan sosial. Salah satu jenis model pembelajaran inovatif adalah video vlog pembelajaran berbasis project, yang merupakan metodologi mendidik dan pembelajaran yang mencakup siswa untuk mengolah suatu usaha sebagai video vlog, video yang dapat bermanfaat bagi masyarakat atau iklim (Sani R, 2013:172). 
Mengingat klarifikasi di atas, model pembelajaran project beased learning merupakan model pembelajaran yang baik untuk diterapkan pada pembelajaran sejarah. Dengan cara seperti itu, peneliti melakukan suatu penelitian dengan judul: "Pengaruh Penerapan Model Project Based Learning Berbasis Video Vlog dalam Proses Pembelajaran Sejarah".

Berdasarkan latar belakang yang telah diuraikan di atas maka rumusan masalah dalam penelitian ini adalah adalah "Adakah Pengaruh Penerapan Model Project Based Learning Berbasis Video Vlog dalam Proses Pembelajaran Sejarah?".

Sesuai dengan rumusan masalah di atas maka tujuan dalam penelitian ini adalah untuk mengetahui ada tidaknya Pengaruh Penerapan Model Project Based Learning Berbasis Video Vlog dalam Proses Pembelajaran Sejarah.

\section{B. METODE PENELITIAN}

Metode penelitian merupakan suatu aturan ilmiah untuk mendapatkan data dengan tujuan dan kegunaan tertentu. Namun dalam penelitian ini mengambil metode Kuantitatif. Metode kuantitatif dikenal dengan teknik tradisional, karena strategi ini telah digunakan cukup lama sehingga menjadi metode untuk penelitian (Sugiyono, 2011:7-8).

Penelitian ini merupakan penelitian dengan bentuk Quasi Eksperimen Design. Penelitian tersebut menyelidiki kemungkinan mengenai sebab dan akibat dimana dalam penelitian secara nyata ada kelompok perlakuan dan ada kelompok kontrol. Kelompok eksperimen dan kelompok kontrol dipilih 2 kelas dari sebagian jumlah populasi, yakni kelas X IPS 1 sebagai kelas kontrol dan $\mathrm{x}$ ips 2 sebagai kelas eksperimen untuk kelompok eksperimen yang mendapat pembelajaran dengan menggunakan model pembelajaran Project Based Learning dan untuk kelompok kontrol yang mendapat pembelajaran dengan menggunakan model pembelajaran konvensional.

Populasi dari penelitian ini berjumlah 62 Siswa dan terdiri dari 2 kelas yaitu kelas X IPS 1 yang berjumlah 30 dan X IPS 2 yang berjumlah 32 siswa. Dalam penelitian menggunakan sampel secara Purposive sampling. Menurut (Arikanto, 2014:183). Purposive Sampling merupakan sebuah pengambilan sampel yang dilakukan degan cara sengaja bukan didasarkan atas random, starta ataupun daerah tetapi didasarkan dengan adanya sebuah tujuan tertentu. Jadi dalam penelitian ini dari kelas X IPS 1 dan X IPS 2 sehingga peneliti mengambil sampel di dalam penelitian ini sebagian dari populasi sebagai sampel yaitu kelas X IPS 2 berjumlah 15 untuk kelas eksperimen dan kelas X IPS 1 berjumlah 15 siswa untuk kelas kontrol.

Teknik pengumpulan data dalam penelitian ini adalah menggunakan teknik tes dan observasi. Tes merupakan serentetan atau latihan yang digunakan untuk mengukur keterampilan, pengetahuan, sikap, intelegensi, kemampuan atau bakat yang dimiliki oleh individu atau kelompok (Riyanto, 2010:103). Tes disini digunakan untuk mengukur mengukur hasil belajar pada aspek kognitif. Instrumen tes yang digunakan dalam penelitian ini berbentuk pilihan ganda.

Teknik analisis data yang digunakan untuk meningkatkan hasil belajar siswa dalam penelitian ini adalah dengan menghitung ratarata dan simpangan baku, uji normalitas data, uji homogenitas dan uji hipotesis. Uji coba instrumen dilaksanakan tanggal 24-29 Mei 2021 di kelas X IPS 1 dan X IPS 2 di UPT SMA Negeri 7 Banyuasin, soal uji coba instrumen Pilihan Ganda berjumlah 30 soal.

\section{HASIL DAN PEMBAHASAN Hasil Penelitian}

Penelitian ini merupakan penelitian dengan bentuk Quasi Eksperimen Design. Penelitian tersebut menyelidiki kemungkinan mengenai sebab dan akibat dimana dalam penelitian secara nyata ada kelompok perlakuan dan ada kelompok kontrol. Kelompok eksperimen dan kelompok kontrol dipilih 2 kelas dari sebagian jumlah populasi, yakni kelas XIPS 1 sebagai kelas kontrol dan X IPS 2 sebagai kelas eksperimen untuk kelompok eksperimen yang mendapat pembelajaran dengan menggunakan model pembelajaran Project Based Learning dan untuk kelompok kontrol yang mendapat pembelajaran dengan menggunakan model pembelajaran 
konvensional. Materi yang dibahas adalah tentang proses masuknya agama Hindu-Budha ke Indonesia.

Uji normalitas data bertujuan untuk mengetahui apakah hasil nilai siswa tersebut berdistribusi normal atau tidak. Dari hasil tes yang diperoleh siswa kelas X IPS 1 dan X IPS 2 baik dengan menggunakan Model Project Based Learning maupun tidak menggunakan model pembelajaran dengan materi proses masuknya agama Hindu-Budha ke Indonesia, dapat dilihat pada tabel sebagai berikut:

Tabel 1

Data Nilai Hasil Tes Kelas Kontrol dan Eksperimen

\begin{tabular}{|c|c|c|c|c|}
\hline Kelas & $\mathbf{N}$ & $\begin{array}{c}\text { Nilai } \\
\text { Tertinggi }\end{array}$ & $\begin{array}{c}\text { Nilai } \\
\text { Terendah }\end{array}$ & $\mathbf{x}$ \\
\hline Eksperimen & 15 & 100 & 70 & 83 \\
\hline Kontrol & 15 & 70 & 30 & 55 \\
\hline
\end{tabular}

Berdasarkan analisis data hasil tes akhir kelas kontrol yang menggunakan strategi atau metode ceramah, dapat diketahui bahwa nilai tertingginya adalah 82 yang didapat 2 orang siswa dan nilai terendahnya adalah 60 yang didapat oleh 2 orang siswa. Sedangkan penilaian tes akhir latihan pada kelas eksperimen yang menggunakan model pembelajaran Project Based Learning materi yang dibahas adalah tentang proses masuknya agama Hindu Budha ke Indonesia dapat diketahui bahwa nilai tertingginya adalah 100 yang didapat 1 orang siswa dan nilai terendahnya adalah 70 yang didapat oleh 3 orang siswa.

\section{Uji Normalitas Data}

\section{Uji Normalitas Data Kelas Kontrol}

\section{Rentang Kelas} kecil.

Rentang $(R)$ kelas $=$ skor besar - skor

$$
\begin{aligned}
R & =100-30 \\
& =70
\end{aligned}
$$

2. Menentukan banyak kelas (BK)

$$
\begin{aligned}
\text { BK } & =1+3,3 \log n \text { (Rumus Sturgerss) } \\
& =1+3,3 \log 30 \\
& =1+3,3(1,477) \\
& =4.87 \text { (dibulatkan menjadi } 5)
\end{aligned}
$$

3. Menentukan panjang kelas interval (i)

$$
\begin{aligned}
I & =\frac{\text { rentang kelas }(\mathrm{R})}{\text { banyak kelas }(B K)} \\
& =\frac{70}{5} \\
& =14
\end{aligned}
$$

\section{Tabel distribusi frekuensi}

Tabel 2

\section{Distribusi Frekuensi Skor Baru Variabel}

\begin{tabular}{|c|c|c|c|c|c|c|}
\hline No & $\begin{array}{c}\text { Kelas } \\
\text { Interval }\end{array}$ & $\mathbf{F}_{\mathbf{i}}$ & $\mathbf{X}_{\mathbf{i}}$ & $\mathbf{F}_{\mathbf{i}} \cdot \mathbf{X}_{\mathbf{i}}$ & $\mathbf{X}_{\mathbf{i}}{ }^{2}$ & $\mathbf{F}_{\mathbf{i}} \mathbf{X}_{\mathbf{i}}{ }^{2}$ \\
\hline 1 & $21-30$ & 1 & 25,5 & 25,5 & 650 & 650 \\
\hline 2 & $31-40$ & 2 & 35,5 & 71 & 1.260 & 2,520 \\
\hline 3 & $41-50$ & 4 & 45,5 & 182 & 2.070 & 8,280 \\
\hline 4 & $51-60$ & 5 & 55,5 & 277,5 & 3.080 & 15,400 \\
\hline 5 & $61-70$ & 6 & 65,5 & 393 & 4.290 & 25,740 \\
\hline 6 & $71-80$ & 7 & 75,5 & 528,5 & 5.700 & 39,900 \\
\hline 7 & $81-90$ & 4 & 85,5 & 342 & 7.310 & 29,240 \\
\hline 8 & $90-100$ & 1 & 95,5 & 95.5 & 9.120 & 9.120 \\
\hline & Jumlah & 30 & 484 & 1.915 & 33.480 & 130.850 \\
\hline
\end{tabular}

5. Menentukan rata-rata atau Mean $(x)$

$$
X=\frac{\sum \int X_{i}}{\int i}=\frac{1.915}{30}=64
$$

6. Menentukan simpangan baku

$$
\begin{aligned}
S & =\sqrt{\frac{n \sum \int x_{i}^{2}-\left(\int x_{i}\right)^{2}}{n \cdot(n-1)}} \\
& =\sqrt{\frac{30.130850-(1.915)^{2}}{30 \cdot(30.1)}} \\
& =\sqrt{\frac{258,275}{870}} \\
& =\sqrt{296,86}=17,22
\end{aligned}
$$

7. Membuat frekuensi yang diharapkan dengan jalan:

a. Membentuk batas kelas, yakni angka nilai pada kelas interval pertama dikurangi 0,5 dan kemudian angka nilai-nilai kanan kelas interval ditambah 0,5 . Sehingga didapat:

20,$5 ; 30,5 ; 40,5 ; 50,5 ; 60,5 ; 70,5 ; 80,5$; 90,5 ; dan 100,5.

b. Mencari nilai Z-score untuk batas kelas interval dengan rumus:

$$
\begin{aligned}
& Z=\frac{\text { batas kelas }-x}{S} \\
& Z_{1}=\frac{20,5-64}{17,22}=-2.52 \\
& Z_{2}=\frac{30,5-64}{17,22}=-1.94 \\
& Z_{3}=\frac{40,5-64}{17,22}=-1,36
\end{aligned}
$$




$$
\begin{aligned}
& Z_{4}=\frac{50,5-64}{17,22}=0,78 \\
& Z_{5}=\frac{60,5-64}{17,22}=0.20 \\
& Z_{6}=\frac{70,5-64}{17,22}=0,37 \\
& Z_{7}=\frac{80,5-64}{17,22}=0,9 \\
& Z_{8}=\frac{90,5-64}{17,22}=1,5 \\
& Z_{9}=\frac{100,5-64}{17,22}=2,11
\end{aligned}
$$

c. Mencari luas $0-Z$ dari Tabel Kurva Normal dari $0-Z$ dengan menggunakan angkaangka untuk batas kelas, sehingga didapat: 0,$4941 ; 0,4738 ; 0,4131 ; 0,2823 ; 0,0793$; 0,$1443 ; 0,3289 ; 0,4370 ; 0,4826$

d. Mencari luas tiap kelas interval dengan jalan mengurangi angka-ang0ka 0-Z, yaitu pada angka baris pertama dikuragi dengan angka pada baris kedua, angka baris kedua dikurangi angka baris ketiga dan seterusnya. Kecuali angka berbeda pada baris paling tengah ditambahkan dengan angka pada baris berikutnya.

$0,4941-0,4738=\mathbf{0 , 0 2 0 3}$

$0,0793-0,1443=\mathbf{0 , 0 6 5}$

$0,4738-0,4131=0,0607$

$0,1443-0,3289=\mathbf{0 , 1 8 4 6}$

$0,4131-0,2823=0,1308$

$0,3289-0,4370=\mathbf{0 , 1 0 8 1}$

$0,2823-0,0793=\mathbf{0 , 2 0 3}$

$0,4370-0,4826=\mathbf{0 , 0 4 5 6}$

e. Mencari frekuensi yang diharapkan (fe) dengan cara mengalikan luas interval dengan jumlah responden $(n=30)$, sehingga didapat:
$0,0203 \times 30=0,60$
$0,065 \times 30=1,95$
$0,0607 \times 30=1,82$
$0,1846 \times 30=5,53$
$0,1308 \times 30=3,92$
$0,1081 \times 30=3,24$
$0,203 \times 30=6,09$
$0,0456 \times 30=1,37$

Tabel 3

Frekuensi yang diharapkan (fe) Dari Hasil Pengamatan (fo) untuk variabel $\mathrm{X}_{2}$

\begin{tabular}{|c|c|c|c|c|c|c|}
\hline No & $\begin{array}{c}\text { Batas } \\
\text { Kelas }\end{array}$ & $\mathbf{Z}$ & $\begin{array}{c}\text { Luas } \\
\mathbf{0 - Z}\end{array}$ & $\begin{array}{c}\text { Luas } \\
\text { Tiap } \\
\text { Kelas } \\
\text { Interval }\end{array}$ & Fe & Fo \\
\hline 1 & 20,5 & $-2,52$ & 0,4941 & 0,0203 & 0,60 & 1 \\
\hline 2 & 30.5 & $-1,94$ & 0,4738 & 0,0607 & 1,82 & 2 \\
\hline 3 & 40,5 & $-1,36$ & 0,4131 & 0,1308 & 3,92 & 4 \\
\hline 4 & 50,5 & 0,78 & 0,2823 & 0,203 & 6,09 & 5 \\
\hline 5 & 60,5 & 0,20 & 0,0793 & 0,065 & 1,95 & 6 \\
\hline 6 & 70,5 & 0,37 & 0,1443 & 0.1846 & 5,53 & 7 \\
\hline 7 & 80,5 & 0,95 & 0,3289 & 0,1081 & 3,24 & 4 \\
\hline 8 & 90,5 & 1,53 & 0,4370 & 0,0456 & 1,37 & 1 \\
\hline & 100,5 & 2,11 & 0,4826 & & & \\
\hline & & & & & & $\sum$ fo $=30$ \\
\hline
\end{tabular}

f. Mencari Chi Kuadrat ( $X^{2}$ hitung) dengan rumus sebagai berikut:

$$
\begin{aligned}
\left(X^{2}\right)= & \sum \frac{(f 0-f e)^{2}}{f e} \\
X^{2}= & \frac{(1-0,60)^{2}}{0.60}+\frac{(2-1,82)^{2}}{1,82} \frac{(4-3,92)^{2}}{3,92}+ \\
& \frac{(5-6,09)^{2}}{6.09}+\frac{(6-1,95)^{2}}{1,95} \frac{(7-5,53)^{2}}{5,53}+ \\
& \frac{(4-3,24)^{2}}{3,24}+\frac{(1-1,37)^{2}}{1,37} \\
= & 0,05+0,36+0,94+0,19+18,77 \\
& +0,05+0,95+0,28 \\
= & 9,56
\end{aligned}
$$

g. Membandingkan ( $\mathrm{X}^{2}$ hitung $)$ dengan $\left(\mathrm{X}^{2}\right.$ tabel $)$ $\mathrm{db}=\mathrm{k}-3=8-3=5$ dan $\mathrm{a}=0,05$ di dapat $\mathrm{X}_{\text {tabel }}=11.071 \mathrm{Kaidah}$ keputusan: Jika, $X^{2}{ }_{\text {hitung }} \geq X^{2}$ tabel, maka distribusi data Tidak Normal Jika, $X^{2}$ hitung $\leq X^{2}$ tabel, maka distribusi data Normal.

Ternyata, $X^{2}$ hitung $\leq X^{2}$ tabel atau $9,56<11,071$, jadi pada penelitian ini data yang diperoleh adalah $\mathrm{X}^{2}$ hitung adalah 9,56 lebih kecil dari $X^{2}$ tabel yakni 11.071 maka dapat disimpulkan bahwa hasil tes akhir belajar pada mata pelajaran IPS dalam penelitian ini berdistribusi normal.

\section{Uji Homogenitas}

Dalam penelitin ini, homogenitas data di uji dengan menggunakan SPSS 20 yakni dengan Levene Statistic. Yang mana data dikatakan homogen apabila nilai Signifikan > 0.05 maka data varians diterima. Dan jika nilai Signifikan $<0,05$ maka data varians ditolak atau tidak homogen. 
Test of Homogeneity of Variances

TINGKAT PENGETAHUAN

\begin{tabular}{|r|c|c|c|}
\hline Levene Statistic & $\mathrm{df1}$ & $\mathrm{df2}$ & Sig. \\
\hline .515 & 1 & 58 & .476 \\
\hline
\end{tabular}

Sumber data: Output SPSS 20 for windows

keputusan:

Langkah-langkah dalam pengambilan

1. Hipotesis

Ho : Varian data homogen

$\mathrm{Ha}$ : Varian data tidak homogeny

2. Data pengambilan keputusan

Probabilitas $>0,05$ maka Ho diterima

Probabilitas < 0,05 maka Ha ditolak

3. Keputusan

Berdasarkan uji homogenitas pada tabel di atas, maka dapat kita lihat bahwa nilai signifikasi hasil sebesar 0,476 dengan $a=$ 0,05 karena 0,476 lebih besar dari Signifikan maka data tersebut bersifat homogen $(0,476>0,05)$. Jadi dapat disimpulkan bahwa hasil tes akhir hasil belajar mata pelajaran IPS dalam penelitian ini bersifat homogen.

\section{Pengujian Hipotesis}

Dalam penelitian ini peneliti menggunakan t-test untuk menguji hipotesis, dengan rumus:

$\mathrm{t}=\frac{X 1-X 2}{\sqrt{\frac{S_{1}^{2}}{n_{1}}+\frac{s_{2}^{2}}{n_{2}}}}$ (Rumus Separated Varians)

\section{Penghitungan Data}

a. Kelas Kontrol

Tabel 4

Distribusi Frekuensi Kelas Kontrol

\begin{tabular}{|c|c|c|c|c|c|c|}
\hline No & $\begin{array}{l}\text { Kelas } \\
\text { Interval }\end{array}$ & $F_{i}$ & $\mathbf{X}_{\mathbf{i}}$ & $F_{i} X_{i}$ & $X_{i}^{2}$ & $F_{i} X_{i}^{2}$ \\
\hline 1 & $21-30$ & 1 & 25,5 & 25,5 & 650 & 650 \\
\hline 2 & $31-40$ & 2 & 35,5 & 71 & 1.260 & 2,520 \\
\hline 3 & $41-50$ & 4 & 45,5 & 182 & 2.070 & 8,280 \\
\hline 4 & $50-60$ & 5 & 55,5 & 277,5 & 3.080 & 15,400 \\
\hline 5 & $61-70$ & 3 & 65,5 & 196.5 & 4,290 & 12,870 \\
\hline \multicolumn{2}{|c|}{ Jumlah } & 15 & 227,5 & 752,5 & 10,091 & 39,720 \\
\hline
\end{tabular}

Mean $(\mathrm{x})$

$X=\frac{\sum \int X_{i}}{\int i}=\frac{752,5}{15}=50,2$

Menentukan simpangan baku

$$
\begin{aligned}
S & =\sqrt{\frac{n \sum \int x_{i}^{2}-\left(\int x_{i}\right)^{2}}{n \cdot(n-1)}} \\
& =\sqrt{\frac{15 \cdot 39720-(752,5)^{2}}{15 \cdot(15-1)}} \\
& =\sqrt{\frac{29,544}{210}} \\
& =\sqrt{3,37}=1,8
\end{aligned}
$$

Varians $\left(\mathrm{s}^{2}\right)$

$(1,8)^{2}=3,24$

\section{b. Kelas Eksperimen}

\section{Tabel 5}

Distribusi Frekuensi Kelas Eksperimen

\begin{tabular}{|c|c|c|c|c|c|c|}
\hline No & $\begin{array}{c}\text { Kelas } \\
\text { Interval }\end{array}$ & $\mathbf{F}_{\mathbf{i}}$ & $\mathbf{X}_{\mathbf{i}}$ & $\mathbf{F}_{\mathbf{i}} \mathbf{X}_{\mathbf{i}}$ & $\mathbf{X}_{\mathbf{i}}{ }^{2}$ & $\mathbf{F}_{\mathbf{i}} \mathbf{X}_{\mathbf{i}}{ }^{2}$ \\
\hline 1 & $61-70$ & 3 & 65,5 & 196,5 & 4.290 & 12,870 \\
\hline 2 & $71-80$ & 7 & 75,5 & 528,5 & 5.700 & 39.900 \\
\hline 3 & $81-90$ & 4 & 85,5 & 342 & 7.310 & 29,240 \\
\hline 4 & $91-100$ & 1 & 95,5 & 95,5 & 9,120 & 9,120 \\
\hline \multicolumn{2}{|c|}{ Jumlah } & $\mathbf{1 5}$ & $\mathbf{3 2 2}$ & $\mathbf{1 . 1 6 2 , 5}$ & $\mathbf{2 6 , 4 2 0}$ & $\mathbf{9 1 . 1 3 0}$ \\
\hline
\end{tabular}

\section{Mean $(\mathrm{x})$}

$X=\frac{\sum \int X_{i}}{\int i}=\frac{1.162,5}{15}=77,5$

Menentukan simpangan baku

$$
\begin{aligned}
S & =\sqrt{\frac{n \sum \int x_{i}^{2}-\left(\int x_{i}\right)^{2}}{n \cdot(n-1)}} \\
& =\sqrt{\frac{15 \cdot 91130-(1.162,5)^{2}}{15 \cdot(15-1)}} \\
& =\sqrt{\frac{15.543,75}{210}} \\
& =\sqrt{74,01}=8,6
\end{aligned}
$$

Varians $\left(\mathrm{s}^{2}\right)$

$(8,6)^{2}=73,96$

Tabel 6

Data Nilai Kelas Eksperimen dan Kelas Kontrol

\begin{tabular}{|c|c|c|}
\hline $\begin{array}{c}\text { Nilai } \\
\text { Sampel }\end{array}$ & Eksperimen & Kontrol \\
\hline $\mathrm{S}^{2}$ & 73,96 & 3,24 \\
\hline $\mathrm{X}$ & 77,5 & 50,2 \\
\hline $\mathrm{N}$ & 15 & 15 \\
\hline
\end{tabular}


Langkah-langkah pengujian hipotesis:

a. Menentukan Hipotesis

Ha: Ada pengaruh media pembelajaran Video Vlog terhadap hasil belajar siswa pada mata pelajaran sejarah di UPT SMA Negeri 7 Banyuasin.

Ho: Tidak ada pengaruh media pembelajaran Video Vlog terhadap hasil belajar siswa pada mata pelajaran sejarah di UPT SMA Negeri 7 Banyuasin.

b. Kriteria Pengujian

Jika thitung $>$ tabel maka Ho ditolak

Jika thitung $<t_{\text {tabel }}$ maka Ha diterima

c. Menentukan taraf signifikan $a=0,05$

d. Menghitung thitung dan tabel

$$
\begin{aligned}
\text { t-test } & =\frac{X 1-X 2}{\sqrt{\frac{s_{1}^{2}}{n_{1}}+\frac{s_{2}^{2}}{n_{2}}}} \\
& =\frac{77,5-50,2}{\sqrt{\frac{73,96}{15}+\frac{3,24}{15}}} \\
& =\frac{27,3}{\sqrt{4,93+0,22}} \\
& =\frac{27,3}{\sqrt{5,15}} \\
& =\frac{27,3}{2,27} \\
& =12,02
\end{aligned}
$$

Dengan taraf signifikasi $\alpha=5 \%$. Kemudian dicari tabel pada tabel distribusi $t$ dengan ketentuan $\mathrm{db}=\mathrm{n}_{1}+\mathrm{n}_{2}-2=15+15-2=$ 28. Sehingga nilai tabel $=1,701$

e. Membandingkan thitung dan tabel Berdasarkan hasil perhitungan di atas diperoleh thitung 12,02. Sedangkan tabel $=1,701$ sehingga diperoleh thitung $=12,02>$ tabel1,701. Jadi Ho ditolak.

f. Pengambilan Keputusan

Karena thitung $=12.02>t_{\text {tabel }}=1,701$, maka ada pengaruh dari model Project Based Learning Berbasis Video Vlog dalam proses pembelajaran sejarah di UPT SMA Negeri 7 Banyuasin.

\section{Pembahasan}

Kegiatan belajar mengajar dengan menerapkan model pembelajaran Project Based Learning Berbasis Video Vlog yakni suatu pembelajaran yang dilakukan dengan cara. Siswa menonton video tentang materi proses masuknya agama Hindu-Budha di Indonesia. Dimana siswa akan lebih mandiri yang tentunya sistem pembelajaran ini akan mampu untuk mendorong keaktifan siswa ketika pembelajaran sedang berlangsung di dalam kelas, dimana siswa menjadi lebih cepat untuk membangun suatu pola fikirnya dari apa yang sedang mereka lihat.

Penelitian ini pernah dilakukan oleh Widowati (2015), Eka Dian Susanti (2019) dan Kinanti Padmi Pratiwi (2018). "Pengaruh Implementasi Model Project Based Learning Terhdap Minat Belajar Sejarah Siswa Kelas X SMA NEGERI 1 Gubug", "Project Based Learning: Pemanfaatan Vlog dalam Pembelajaran Sejarah Untuk Generasi Pro Gadget" dan "Penerapan Model Pembelajaran Project Based Learning Untuk Meningkatkan Keaktifan dan Motivasi Belajar Siswa Mata Pelajaran Simulasi dan Komunikasi Digital di SMKN 2 Klaten". Persamaan penelitian terdahulu dengan penelitian ini adalah samasama meneliti mengenai penerapan model pembelajaran Project Baseed Learning.

Penerapan model pembelajaran Project Based Learning Berbasis Video Vlogini belum pernah diterapkan di UPT SMA Negeri 7Banyuasin. Sampel yang digunakan peneliti pada penelitian ini yaitu purposive sampling atau pengambilan sampel yang dilakukan dengan sengaja dengan mengambil 2 kelas $X$ sebagai sampel dari penelitian. Jadi sampel pada penelitian ini yakni kelas X IPS 2 sebagai kelas eksperimen yang berjumlah 15 siswa, dan kelas X IPS 1 sebagai kelas kontrol yang berjumlah 15 siswa. Variabel X/variabel bebas dalam penelitian ini yakni model pembelajaran Project Based Learning Berbasis Video Vlog dan variabel Y/variabel terikat yakni hasil belajar siswa.

Untuk mengetahui pengaruh penerapan dari model pembelajaran Project Based Learning Berbasis Video Vlog dalam Proses Pembelajaran Sejarah dibuktikan menggunakan t-test, namun sebelum menggunakan rumus ini, data penelitian harus memenuhi uji prasyarat yakni data berdistribusi normal dan data bersifat homogen. Dengan diperoleh $\mathrm{X}^{2}$ hitung $\leq \mathrm{X}^{2}$ tabel atau $.9,56<11,071$, jadi dapat disimpulkan bahwa hasil tes akhir dalam penelitian ini berdistribusi Normal. Sedangkan untuk uji homogenitasnya dapat dilihat pada tabel bahwa 
nilai signifikasi hasil sebesar 0,476 dengan $\alpha=$ 0,05 . Karena 0,476> 0,05 maka dapat disimpulkan bahwa hasil tes akhir dalam penelitian ini bersifat homogen.

Hasil analisis hipotesis menggunakan Independent Sample Test menunjukan bahwa ada pengaruh penerapan model pembelajaran Project Based Leearning Berbasis Video Vlog dalam proses prmbelajaran sejarah. Karena $t_{\text {hitung }}=12.02>t_{\text {tabel }}=1,701$, dan dilihat dari kenaikan nilai rata-rata yang sebelumnya 71 menjadi 83, dan dengan perhitungan persentase yakni naik sebanyak $12 \%$. Maka ada pengaruh Penerapan model pembelajaran Project Based Learning Berbasis Video Vlog dalam ProsesPembelajaran Sejarah.

\section{SIMPULAN}

Berdasarkan hasil penelitian yang dilakukan oleh peneliti, dapat disimpulkan bahwa hasil dari pengujian hipotesis menunjukkan bahwa adanya pengaruh penerapan model project based learning berbasis video vlog dalam proses pembelajaran sejarah. Hal ini dapat dilihat dari:

1. Hasil penelitian pengaruh penerapan model project based learning berbasis video vlog dalam proses pembelajaran sejarah, yakni dibuktikan dengan perhitungan dari t-test yang dimana hasil karena thitung $=9,56>t_{\text {tabel }}=1,701$ maka $\mathrm{Ho}$ ditolak dan Ha diterima. Dan dilihat dari kenaikan nilai rata-rata yang sebelumnya 55 menjadi 83, dan dengan perhitungan persentase yakni naik sebanyak $6 \%$.

2. Dari hasil penelitian ini dapat diamati bahwa kelas yang dijadikan kelas uji/eksperimen dengan menerapkan model pembelajaran ini lebih berpengaruh untuk siswa dalam mengikuti kegiatan pembelajaran yang memanfaatkan internet dan media digital dalam penyampaian materi oleh karena itu siswa dituntut untuk belajar dengan kondusif dan tetap harus fokus dalam menerima pelajaran yang disampaikan oleh guru.

\section{DAFTAR PUSTAKA}

Ahyani Nur. (2014). Kemampuan Berfikir Kritis dalam Pembelajaran Sejarah. fkip.uns. Hal. 94 .

Arikanto, S. (2014). Prosedur Penelitian Suatu Pendekatan Praktik. Jakarta: Rineka Cipta.

Fakhrurrazi. (2018). Hakikat Pembelajaran yang Efektif. At-Takhfir.

Riyanto,Yatim. 2009. Paradigma Baru Pembelajaran: Sebagai Referensi bagi Pendidikan dalam Implementasi Pembelajaran yang Efektif dan Berkualitas. Jakarta: Penanda Media Group.

Sani, R. (2013). Pembelajaran Saintificuntuk Implemtasi Kurikulum 2013. Jakarta: PT Bumi Aksara.

Sugiyono. (2011). Metode Penelitian Kuantitatif, Kualitatif dan R\&D. Bandung: Alfa Beta. 


\section{KETENTUAN PENULISAN ARTIKEL JURNAL KALPATARU}

1. Naskah berbahasa Indonesia yang disempurnakan bertemakan kesejarah yang meliputi hasil penelitian sejarah, pengajaran sejarah dan penelitian kebudayaan.

2. Naskah harus asli dan belum pernah dimuat dalam media lain. Naskah dapat berupa hasil penelitian/artikel kajian konseptual yang ditulis oleh perorangan dan atau kelompok.

3. Naskah ditulis dengan cara-cara yang sesuai dengan ketentuan penulisan artikel ilmiah menggunakan bahasa Indonesia yang baku, berupa ketikan, beserta soft file dalam CD-RW atau dengan mengirimkan email pada redaksi jurnal Kalpataru dengan alamat jurnalkalpatarusejarah@gmail.com, spasi tunggal, jenis huruf arial narrow ukuran 12, dengan panjang naskah antara 8-15 halaman pada kertas A4.

4. Artikel hasil penelitian memuat:

JUDUL

Nama Penulis

Abstrak

\section{: XXX (HURUF KAPITAL)}

: (disertai jabatan, institusi, dan email)

: (Bahasa Indonesia yang memuat 100-200 kata diikuti kata kunci, dengan jenis huruf arrial narrow dan ukuran huruf 11 serta dicetak miring). masalah penelitian, dan tujuan penelitian).

\section{B. METODE PENELITIAN}
: (memuat latar belakang masalah, tinjauan pustaka secara ringkas,
A. PENDAHULUAN

C. HASIL DAN PEMBAHASAN

D. SIMPULAN

: (berisi simpulan).

DAFTAR PUSTAKA : : (berisi pustaka yang dirujuk dalam uraian naskah).

5. Artikel Kajian Konseptual memuat:
JUDUL
: XXX (HURUF KAPITAL)
Nama Penulis
Abstrak
: (disertai jabatan, institusi, dan email)
: (Bahasa Indonesia yang memuat 100-200 kata diikuti kata kunci, dengan jenis huruf arrial narrow dan ukuran huruf 11 serta dicetak miring.
PENDAHULUAN
: (memuat latar belakang masalah, tinjauan pustaka secara ringkas, masalah penelitian, dan tujuan penelitian).
Sub Judul
: Sesuai dengan kebutuhan (tanpa numbering).
Simpulan
DAFTAR PUSTAKA
: (berisi simpulan dan saran).

6. Referensi sumber dalam teks artikel ditulis dengan menggunakan side note, contoh (Jalaludin, 1991:79); sementara penulisan daftar pustaka disusun dengan ketentuan. Nama pengarang. Tahun terbit. Judul (dicetak miring). Kota terbit: Nama Penerbit. Contoh: Koentjaraningrat. 2010. Manusia dan Kebudayaan di Indonesia. Jakarta: Djambatan. Daftar pustaka hanya memuat pustaka/sumber yang dirujuk dalam uraian dan disusun menurut abjad tanpa nomor urut.

7. Naskah yang dimuat akan disunting kembali oleh redaksi tanpa mengubah isinya.

8. Naskah yang ditolak (tidak bisa dimuat) akan dikirim kembali ke penulis dengan pemberitahuan tertulis dari redaksi atau melalui email.

9. Penulis yang naskahnya dimuat akan mendapat 1 (satu) majalah nomor yang bersangkutan.

10. Kontak person: Muhamad Idris (081271498618); Eva Dina Chairunisa (082281267851); Jeki Sepriady (085269261780). 